Article

\title{
SOIL AND GRASSLAND EFFECTS ON GRASSLAND NET PHOTOSYNTHESIS IN GANNAN, CHINA, FROM 2000 TO
}

\section{8}

\author{
Stephen Nazieh ${ }^{1}$, Meiling Zhang ${ }^{1, *}$, Teddy Nkrumah ${ }^{1}$, Xingyu Wang ${ }^{1}$, Shanglang Hong ${ }^{1}$ \\ 1 Applied Statistics, College of Science, Gansu Agricultural University, Lanzhou 730070, China \\ * Correspondence: zhangml@gsau.edu.cn
}

Stephen Nazieh and Meiling Zhang have contributed equally to this work.

\begin{abstract}
What is the ideal soil-grass combination for maximum photosynthesis? In this study, we investigated how soil and grassland types affect photosynthesis in the grasslands of Gannan, China. We divided the grasslands of Gannan into 166 study sites, each with a unique soil-grass combination by intersecting the soil and ecoregion maps using ArcGIS. We obtained 19 years of data on the Net Photosynthesis (PsnNet) of grasslands in the area from 2000 to 2018 and then divided them into "growing season" (June to September) and "non-growing season" (October top May). Between 2000 and 2018, PsnNet of grasslands showed a gradually increasing trend. The effect of soil type on PsnNet was not significant during the growing season. However, it was highly significant during the non-growing season. Among the soil types, grasses that grew in Mollic, Gelic, and Haplic soils had the highest rate of photosynthesis. The difference in PsnNet among the various grass types was highly significant during both seasons. However, Tropical and Subtropical succulent evergreen broad-leaf shrubs and Temperate meadows had the highest rate of photosynthesis. Additionally, there was a highly significant difference in PsnNet among the various soil-grass interactions. In the growing season, TStEgBLS growing Eutric soils had the highest PsnNet. However, SaDBLS growing in Gelic soils had the the highest.
\end{abstract}

Keywords: Net Photosynthesis, Soil, Grassland, Mollic, Gelic, Eutric

\section{Introduction}

The role of grasslands in the energy and matter exchange between the land's surface and the atmosphere cannot be overemphasized. They play a crucial role in the assimilation of atmospheric carbon dioxide through photosynthesis. Light energy is a key factor in this process. Generally, photosynthesis that occurs in the presence of light is called photorespiration. However, dark or mitochondrial photosynthesis can occur with or without light energy. When photorespiration and dark photosynthesis are subtracted from true photosynthesis, net photosynthesis is obtained [1]. Photosynthesis is essential for the reduction of atmospheric carbon, thereby slowing global warming.

Several strategies have been devised to absorb the fast-growing amounts of atmospheric carbon. One such strategy is afforestation and reforestation [2-5]. Research shows that grasslands have a high potential to sequester more carbon in the soil [6]. However, they face problems of shrinkage and degradation $[7,8]$ owing to overgrazing and poor 
management practices. To overcome these problems, it is necessary to devise more advanced methods to enhance grassland productivity. This involves a deeper understanding and appreciation of the roles of soil and grassland types in grassland productivity. This would not only provide us with clarity, but also help us appreciate the global carbon cycle [9].

Gannan is one of the largest repositories of the grasslands of China; therefore, it holds a significant interest in the study of the terrestrial carbon cycle of China and global carbon cycle research. As a result, many studies have been conducted in and around this area concerning grassland productivity. According to available literature, soil and grassland types affect grassland productivity [10-14]. For instance, Misra et al. observed that distinct species of grass have varying concentrations of chlorophyll [15], which can greatly affect the rate of photosynthesis. Additionally, the effect of soil conditions on productivity was demonstrated by $\mathrm{Wu}$ et al. [16] and Chen et al. [17] on the Loess Plateau of China. They showed that soil conditions are variable and therefore affect their ability to support plant life. In summary, the role of soil in grassland productivity needs immediate attention in the study of global warming.

Studies on the effects of soil and grassland types on productivity have often been conducted in isolation, ignoring the soil-vegetation interaction effect. In this study, we investigated the effects of grass and soil types as well as their interaction effects on the net photosynthesis (PsnNet) of grasslands. We accomplished this by capitalizing on the soil and grassland diversity of Gannan and the availability of remote sensing data. Large area surveys are possible, thanks to the availability of remote sensing technology.[18]. Although Gannan is home to a variety of grassland types growing in a diverse range of soil groups, a study of this nature in this area has not been reported

Using linear mixed-effects (LME) models, this study aims to: (1) determine how soil and vegetation types affect the PsnNet of grasslands in Gannan, China. (2) determine which soil-grass combination has the highest PsnNet. (3) determine the changes in PsnNet from growing to non-growing seasons. Our study provides more clarity on the ecosystem and how particular soil types support particular grasses. It will also provide policymakers with new insights into grassland restoration programs and environmental decision-making processes.

\section{Materials and Methods}

\subsection{Study Area}

The Gannan Prefecture is located in the South of Gansu and North of the QinghaiTibetan Plateau, between longitudes $100^{\circ} 45 \mathrm{E}$ and $104^{\circ} 45 \mathrm{E}$ and Latitudes $33^{\circ} 06 \mathrm{~N}$ and $35^{\circ} 44 \mathrm{~N}$ (Figure 1). 


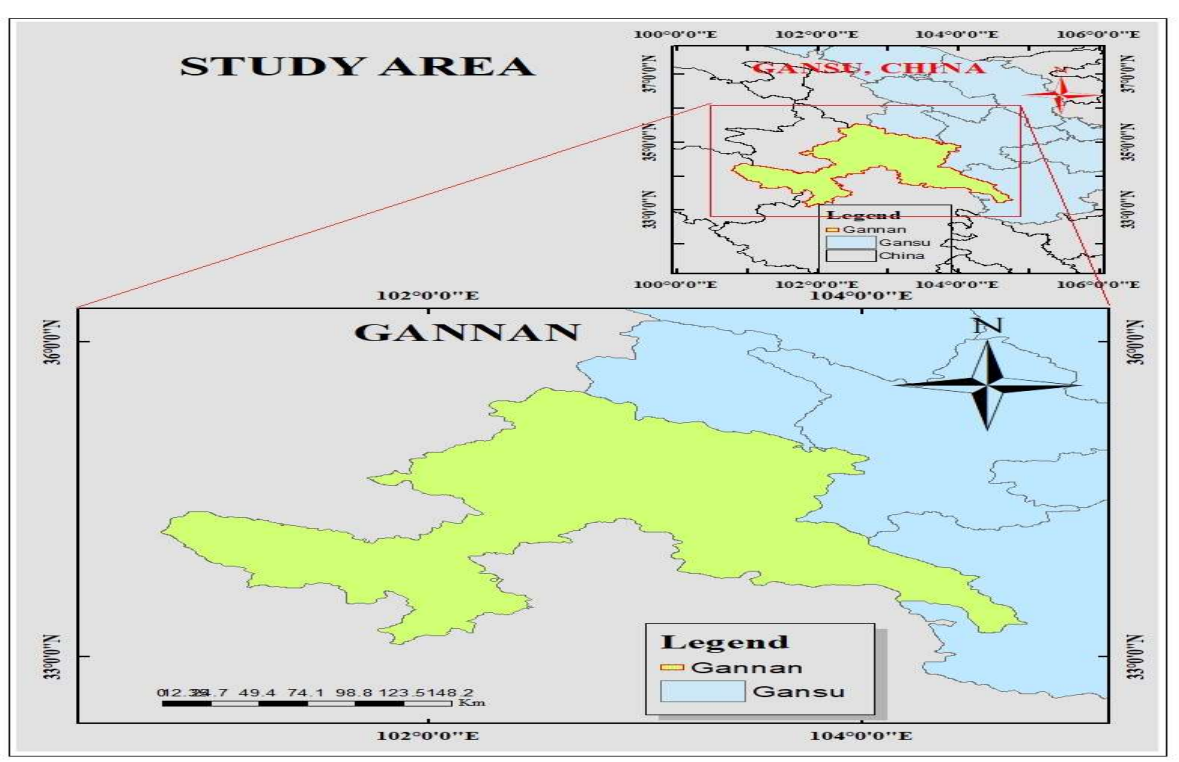

Figure 1. Study Area: Gannan Prefecture, Gansu-China

The elevation ranges between 1172m (about the height of the Burj Khalifa, the tallest building in the world) and $4777 \mathrm{~m}$ (about half the cruising altitude of a commercial jet) above sea level. Temperatures are between $-30.6{ }^{\circ} \mathrm{C}$ and $28.9{ }^{\circ} \mathrm{C}$ with annual means between 1 ${ }^{\circ} \mathrm{C}$ and $3{ }^{\circ} \mathrm{C}$. The annual precipitation varies from 400 to $800 \mathrm{~mm}$ (about the length of a baseball bat), with potential evapotranspiration of 1200-1350 mm (about half the height of a regulation basketball hoop) [19]. High-elevation areas experience cold summers. However, areas with low elevations experience warm summers. There is snow cover in the high mountains during the winter season.

The area is characterized by nineteen soil types. These were further classified into ten major groups: Mollic, Haplic, Gelic, Eutric, Calcic, Dystric, Luvic, Terric, Fibric, and Calcaric soils (Table 1). There are fourteen grassland types including Tropical and Subtropical Succulent Evergreen Broad-Leaf Shrubs, Temperate Deciduous Broad-Leaf Shrubs, SubAlpine Deciduous Broad-Leaf Shrubs, Sub-Alpine Hard-Leaf Evergreen Broad-leaf Shrubs, Alpine Cushion, Temperate Meadows, Marsh Meadows, Tibetan Caragana \& Dwarf Grass Desert, Thorn weed, Halophyte, Alpine Meadows, Temperate Typical, and Alpine Sparse [20, 21]. The most dominant include Temperate Typical, Alpine Meadow, Typical Meadow, and Temperate Deciduous (Table 2). Grasslands cover $65 \%$ of the total land surface.

Table 1. Soil distribution in Gannan [21]

\begin{tabular}{ccc}
\hline Soil Type & Area(SqKm) & \% \\
\hline Eutric & 10755.797 & 40.717 \\
\hline Calcic & 7596.000 & 28.755 \\
\hline Luvic & 2874.230 & 10.881 \\
\hline Mollic & 2836.160 & 10.736 \\
\hline Terric & 812.480 & 3.076 \\
\hline Calcaric & 618.666 & 2.342 \\
\hline Gleyic & 501.496 & 1.898 \\
\hline Haplic & 330.337 & 1.251 \\
\hline Gelic & 40.347 & 0.153 \\
\hline Fibric & 29.360 & 0.111 \\
\hline
\end{tabular}




\begin{tabular}{ccc}
\hline Dystric & 21.436 & 0.081 \\
\hline Total & $\mathbf{2 6 4 1 6 . 3}$ & $\mathbf{1 0 0}$ \\
\hline
\end{tabular}

Table 2. Grassland distribution in Gannan [20]

\begin{tabular}{ccc}
\hline Grassland Type & Area(SqKm) & $\mathbf{\%}$ \\
\hline Alpine Meadows & 11470.283 & 43.421 \\
\hline Subalpine deciduous broad-leaf shrubs & 10633.698 & 40.254 \\
\hline Subalpine hard-leaf evergreen broad-leaf shrubs & 1942.058 & 7.352 \\
\hline Temperate deciduous broad-leaf shrubs & 964.822 & 3.652 \\
\hline Typical meadows & 396.847 & 1.502 \\
\hline Tempe rate Typical & 353.485 & 1.338 \\
\hline Alpine sparse & 231.224 & 0.875 \\
\hline Halophytes & 144.648 & 0.548 \\
\hline Alpine Cushion & 104.741 & 0.397 \\
\hline Thorn weed & 100.741 & 0.381 \\
\hline Tropical and subtropical succulent evergreen broad- \\
leaf shrubs & 51.732 & 0.196 \\
\hline Temperate meadows & 16.576 & 0.063 \\
\hline Marsh meadows & 4.674 & 0.018 \\
\hline Total & 0.566 & 0.002 \\
\hline
\end{tabular}

\subsection{Data}

\subsubsection{Terrestrial Eco-regions:}

The ecoregion database of China is available at http://www.ecosystem.csdb.cn [20]. It is a repository of the spatial distribution of ecosystem classifications freely available in vector format. It comprises the spatial distribution patterns of various ecosystems across the country, such as forests, grasslands, shrubs, farmland, towns, deserts, bare land, and other ecosystems.

\subsubsection{Soil data}

We obtained soil data from the Harmonized World Soil Database Version 1.2 (HWSD V1.2) [21] in a vector format. This version was compiled from: the European Soil Database (ESDB), the soil map of China, a number of regional SOTER databases, and the Soil Map of the World [21]. This was a collaborative among the ISRIC-World Soil Information, the FAO, the European Soil Bureau Network, and the Institute of Soil Science, Chinese Academy of Sciences. The Soil Map of China was based on data from the Second National Soil Survey of China in 1995 and distributed by the Institute of Soil Science in Nanjing [22].

\subsubsection{Net Photosynthesis (PsnNet)}

We downloaded the MOD17A2HGF Version 6 Net Photosynthesis (PsnNet500) product from lpdaac.usgs.gov [23]. The gap-filled MOD17A2HGF is an improved version of MOD17, which has as input, the cleaned poor-quality 8-day Leaf Area Index and Fraction of Photosynthetically Active Radiation. MOD17A2HGF is a cumulative 8-day composite of values based on the radiation use efficiency concept at a resolution of $500 \mathrm{~m}$. The PsnNet (kg C day-1) values were calculated from gross primary production (GPP) and maintenance respiration as:

$$
\text { PsnNet }=\text { GPP }- \text { Leaf_MR }- \text { Froot_MR. }
$$


where GPP is the initial daily total of photosynthesis and daily net photosynthesis (PsnNet), and Leaf_MR and Froot_MR are leaf and fine-root respiration respectively. [23, 24].

\subsection{Method}

\subsubsection{Data Preparation}

The soil and vegetation maps in vector format were intersected using the ArcGIS intersect tool to produce a map of 166 sites. Each site is a unique combination of soil and grassland types as shown in Table 3.

Table 3. Site Composition [20, 25]

\begin{tabular}{cccc}
\hline $\begin{array}{c}\text { Site } \\
\text { ID }\end{array}$ & Soil & Grass Type & $\begin{array}{c}\text { Area } \\
\text { (Sqm) }\end{array}$ \\
\hline 0 & Eutric & Temperate deciduous broad-leaf Shrub & 4270000 \\
\hline 1 & Eutric & Temperate Typical & 850000 \\
\hline 2 & Eutric & Temperate deciduous broad-leaf Shrub & 3410000 \\
\hline 3 & Eutric & Subalpine hard-leaf evergreen Broad-leaf Shrub & 21620000 \\
\hline$\ldots$ & $\ldots$ & $\ldots$ & $\ldots$ \\
\hline 23 & Gleyic & Alpine Meadow & 40340000 \\
\hline 24 & Calcaric & Alpine Meadow & 6210000 \\
\hline 25 & Calcaric & Subalpine deciduous broad-leaf shrub & 4260000 \\
\hline 26 & Calcaric & Alpine Meadow & 201630000 \\
\hline$\ldots$ & $\ldots$ & $\ldots$ & $\ldots$ \\
\hline 135 & Terric & Alpine meadows & 12630000 \\
\hline 136 & Terric & Alpine meadows & 276490000 \\
\hline 137 & Terric & Subalpine deciduous broad-leaf shrub & 33830000 \\
\hline 138 & Terric & Alpine Meadow & 173.920000 \\
\hline 139 & Fibric & Subalpine deciduous broad-leaf shrub & 1550000 \\
\hline 140 & Dystric & Alpine Meadow & 19890000 \\
\hline 162 & Mollic & Alpine Sparse & 4850000 \\
\hline 163 & Mollic & Thorn weed & 51170000 \\
\hline 164 & Haplic & Marsh Meadow & 0.570000 \\
\hline 165 & Haplic & Thorn weed & 570000 \\
\hline & & &
\end{tabular}

Using QGIS, the area of each site was computed in square meters. The resulting map was used as input for the lpdaac Application for Extracting and Exploring AnalysisReady Samples (AppEARS) data tool to extract the PsnNet values for each site. This is a cumulative 8-day composite of values within each month. Therefore, for each site, the average net photosynthesis at $500 \mathrm{~m}$ resolution for each month was calculated as:

$$
\text { AvPsnNet500 }\left(\mathrm{M}^{\mathrm{x}}\right)=\left(1^{\text {st }} 8 \text { days }+2^{\text {nd }} 8 \text { days }+\ldots+\mathrm{n}^{\text {th }} 8 \text { days }\right) / \mathrm{n}
$$

where AvPsnNet500(Mx) is the average net photosynthesis $\left(\mathrm{kgC} / 8\right.$ day) in month $\mathrm{M}^{\mathrm{x}}$ at $500 \mathrm{~m}$ resolution.

By proportion, we obtained the mean PsnNet for each site in any given month as:

$$
\operatorname{AvPsnNetSID}=\left(\mathrm{A}^{\mathrm{SID}} * \text { AvPsnNet500(M) }\right) / 500
$$

where AvPsnNetSID is the PsnNet (kgC/8day) at site SID in any given month, and $\mathrm{A}^{\text {SID }}$ is the area of site SID (sqm). 
We split the entire data into growing season (June to September) and non-growing season (October to May).

For the same site, we computed the percentage change in PsnNet between the growing and non-growing seasons for the various soil-grass interactions as:

$\%$ CPsnNet $=\left[(\right.$ AvPsnNetSID Gs - AvPsnNetSID NGS $) /$ AvPsnNetSID GS ${ }^{* 100}$

where \%CPsnNet is the percentage change in net photosynthesis between the growing and non-growing seasons, PsnNet ${ }^{\mathrm{GS}}$ is the net photosynthesis in the growing season, and PsnNet ${ }^{\mathrm{NGS}}$ is the net photosynthesis in the non-growing season.

We employed a split-plot design with a mixed-effects (random and fixed) model to analyze the effects of soil and grassland as well as their interaction on PsnNet. Grass types were manipulated at the subplot level and the soil type was manipulated at the plot level. Grass and soil types were treated as random effects. "Block" was set as a fixed factor. The response variable was PsnNet (KgC/8day).

\subsubsection{Statistical Analyses}

All statistical analyses were performed using the RStudio Version 1.4.1096. ArcGIS version 10.16 and QGIS version 3.16.2 were used for all map-related tasks. The summary statistics were computed using Microsoft Excel 2016. In all cases, $P \leq 0.05,0.01$, and 0.001 were considered significant, moderately, and highly significant respectively. Linear mixed-effects model (LME) analysis was performed to test the possible dependency of grassland photosynthesis on soil and vegetation types. A post hoc test for pair-wise comparison of means was conducted using the Tukey-LSD test.

\section{Results}

\subsection{Temporal Distribution of PsnNet}

Figure 2 shows the temporal dynamics of grassland net photosynthesis (at $500 \mathrm{~m}$ resolution) in Gannan between 2000 and 2018. Figures 2A and B show the annual and monthly scales respectively. Each value represents the average net photosynthesis for the corresponding year or month. It shows a gradually increasing trend, which is an indication of improving vegetation health over the years.
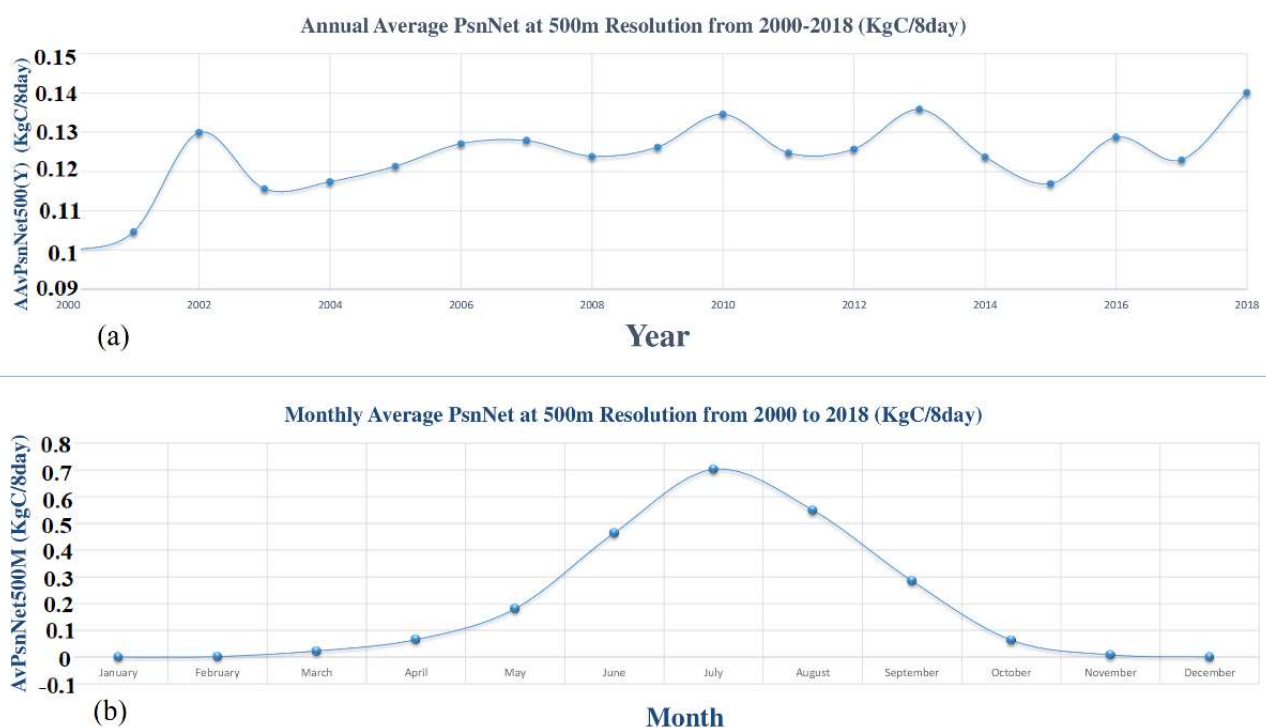

(b)

Month 
Figure 2. Temporal Distribution of PsNet at 500m resolution (KgC/8day) (A) Annual scale (B) Monthly scale

Photosynthesis peaked in July and dropped below 0.0 in December and January.

\subsection{Spatial Distribution of Net Photosynthesis}

Figure 3 shows the spatial distribution of net photosynthesis in Gannan between 2000 and 2018. The values represent the average photosynthesis at $500 \mathrm{~m}$ resolution for the respective range of years. These values were calculated using ArcGIS zonal statistics tool. The spatial distribution indicated that net photosynthesis decreased from the southeast to the southwest.

\section{SPATIAL DISTRIBUTION OF PsnNet at 500m RESOLUTION}

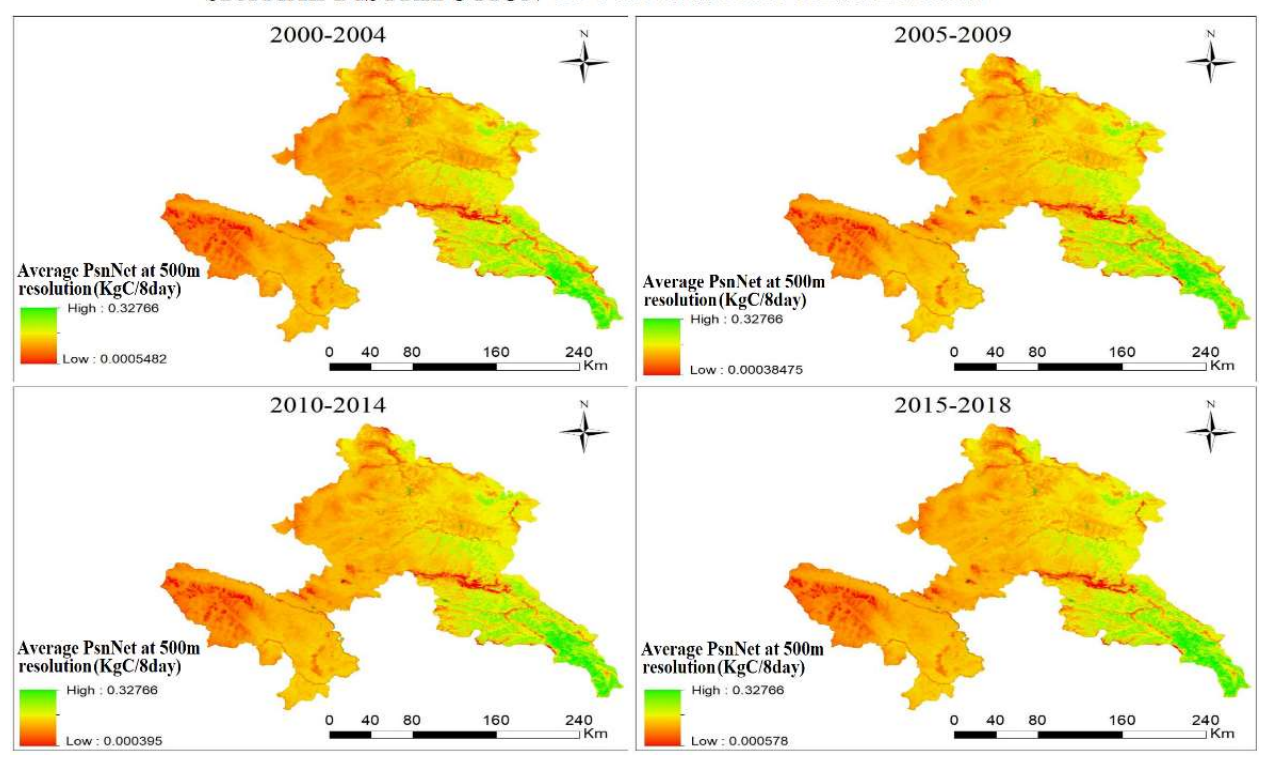

Figure 3. Spatial Distribution of PsnNet. This is the average of NPP from 2000-2004, 20052009, 2010-2014, and 2015-2018 respectively.

The southeastern region is dominated by Tropical succulent evergreen broadleaf and Subalpine hard-leaf evergreen broad-leaf shrubs [19]. These are perennial woody plants with persistent woody stems above the ground. The southwestern region is dominated by Alpine meadows. In this area, elevation may reach over $4700 \mathrm{~m}$ above sea level. During winter, the area is usually covered by snow and the summers are also cold. Water runoff is also a common phenomenon in the alpine regions as compared to the subalpine regions. As a result, the subalpine regions are well hydrated year-round. This is why spatial location has a highly significant effect on net photosynthesis during the non-growing season. However, in the growing season, location (block) had a significant effect on net photosynthesis (Table 4).

Table 4. ANOVA of Grassland and location effect on PsnNet (a) Growing Season (b) Non-growing Season. Significance codes: $0^{* * * \prime} 0.001^{* * *^{*}} 0.01^{* \prime \prime} 0.05^{\prime}$.

\begin{tabular}{cccccc}
\hline \multicolumn{7}{c}{ ANOVA (Growing season) } \\
\hline & Df & Sum Sq & Mean Sq & F-Value & $\operatorname{Pr}(>\mathrm{F})$ \\
\hline block & 3 & 0.00073 & $2.40 \mathrm{E}-04$ & 3.59 & $0.04645^{*}$ \\
\hline Grass & 12 & 0.00164 & $1.36 \mathrm{E}-04$ & 5.85 & $0.000001613^{* * *}$ \\
\hline
\end{tabular}

(a) 


\begin{tabular}{cccccc}
\hline \multicolumn{7}{c}{ ANOVA (Non-Growing season) } \\
\hline & Df & Sum Sq & Mean Sq & F-Value & $\operatorname{Pr}(>\mathrm{F})$ \\
\hline block & 3 & 02.33E-05 & 7.77E-06 & 196.122 & $5.30 \mathrm{E}-15^{* * *}$ \\
\hline Grass & 13 & $2.59 \mathrm{E}-04$ & $1.99 \mathrm{E}-05$ & 44.407 & $2.20 \mathrm{E}-16^{* * *}$ \\
\hline
\end{tabular}

(b)

This could also be attributed to the fact that some soil types have higher water retention capacity, thereby supporting plant growth even in the absence of rain, especially in the subalpine regions.

\subsection{Effects of Grassland type on Productivity.}

Figure 4 shows the annual net photosynthesis by grassland type from 2000 to 2018 in Gannan. Tropical and Subtropical succulent Evergreen Broad-leaf Shrubs (TSTSEgBLS) and Temperate Meadows (TM) proved to have the highest PsnNet (KgC/8day) at 500m resolution and showed an increasing trend for the study period while the rest were flat (Figure 4). Although Alpine Meadows (AM) are the dominant grassland type, a comparison of the PsnNet at 500m resolution of the various grass types shows that they have a relatively low rate of photosynthesis.

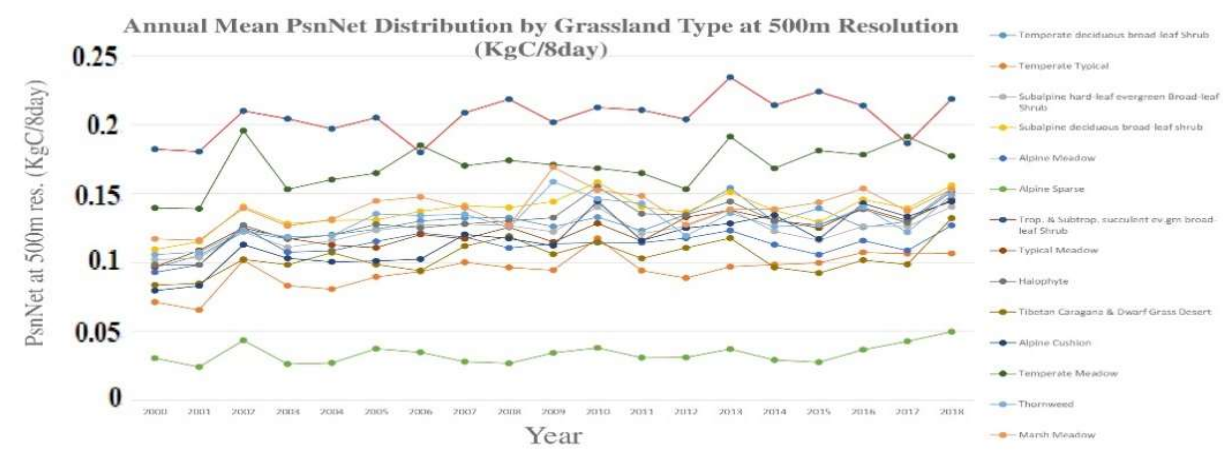

Figure 4. Annual Dynamics of PsnNet by Grassland Type (KgC/8day)at 50-0m resolution.

Alpine sparse (AS) had the lowest rate of photosynthesis followed by Marsh Meadows (MM). As shown in Table 4, grassland type had a highly significant effect on net photosynthesis in both the growing (Table 4A) and non-growing (Table 4B) seasons.

On a monthly scale, Temperate meadows (TM) perform best between June and August, dropping, however, below Tropical and Subtropical succulent evergreen broad-leaf Shrubs (TStSEgBLS) which maintain the highest rate of photosynthesis until mid-May. Throughout the year TM and TStSEgBLS maintained the highest PsnNet (Figure 5). 


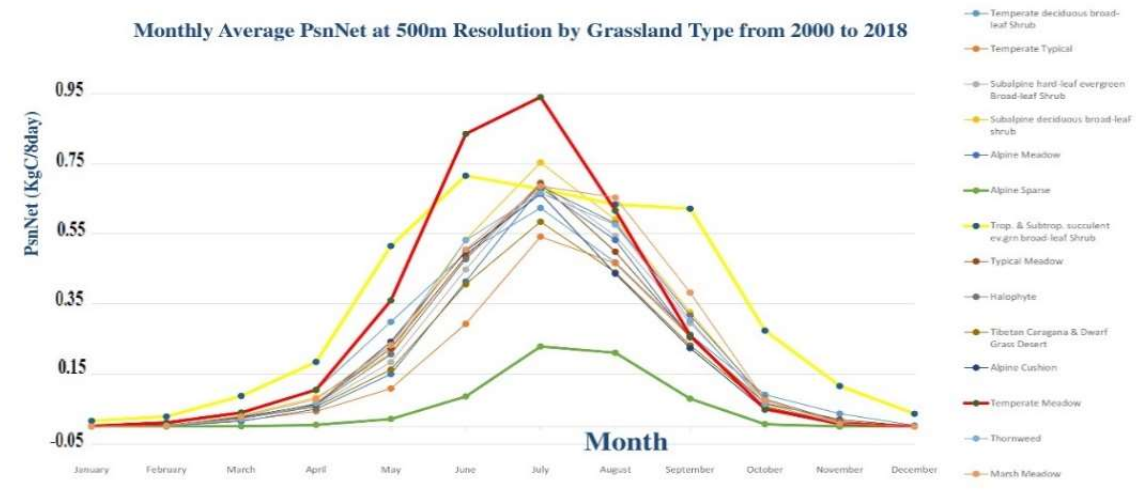

Figure 5. Monthly Mean PsnNet Distribution at 500m resolution (KgC/8day) from 2000 to 2018

\subsection{Effect of Soil type on PsnNet}

We were also interested in determining which soil types supported which grassland types. Figure 6 shows the PsnNet distribution according to the soil type in which particular grasses grow. The values are the net photosynthesis by the coverage area of the respective soil-grass type interaction. Grasses that grow in Mollic, Gelic, Haplic, and Eutric soils have the highest net photosynthesis, with those growing in Fibric soils having the least. (Figures. 6A and B).
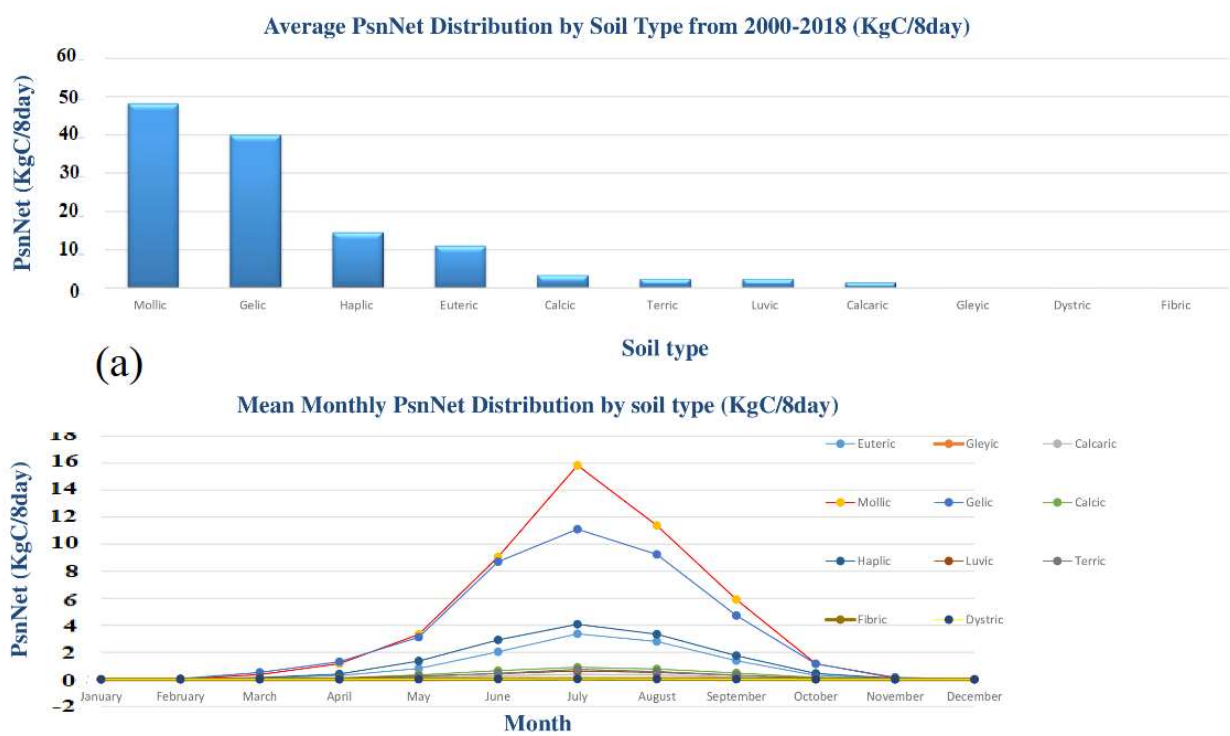

(b)

Figure 6. PsnNet Distribution by Soil Type from 2000 to 2018 (KgC/8day)(A) Mean PsnNet by soil type. (B) Monthly Mean PsnNet distribution.

In the growing season, soil type had no significant effect on net photosynthesis (Table $5 \mathrm{~A})$. However, in the non-growing season, it had a highly significant effect. (Table 5B)

Table 5. ANOVA of Soil effect on PsnNet (a) Growing Season (b) Non-growing Sea-

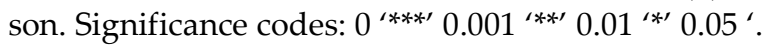




\begin{tabular}{cccccc}
\hline \multicolumn{7}{c}{ ANOVA (Growing season) } \\
\hline & Df & Sum Sq & Mean Sq & F-Value & $\operatorname{Pr}(>\mathrm{F})$ \\
\hline block & 3 & 0.00073 & $2.40 \mathrm{E}-04$ & 3.59 & $0.04645^{*}$ \\
\hline Soil & 10 & 0.00108 & $1.08 \mathrm{E}-04$ & 1.62 & 0.2124 \\
\hline
\end{tabular}

(a)

\begin{tabular}{cccccc}
\hline \multicolumn{7}{c}{ ANOVA (Non-Growing season) } \\
\hline & Df & Sum Sq & Mean Sq & F-Value & $\operatorname{Pr}(>\mathrm{F})$ \\
\hline block & 3 & $02.33 \mathrm{E}-05$ & $7.77 \mathrm{E}-06$ & 196.122 & $5.30 \mathrm{E}-15^{* * *}$ \\
\hline Soil & 10 & $1.03 \mathrm{E}-04$ & $1.03 \mathrm{E}-05$ & 260.289 & $2.20 \mathrm{E}-16^{* * *}$ \\
\hline
\end{tabular}

(b)

From the grouping analyses, it was confirmed that soil type does not cause much variation in net photosynthesis during the growing season (Figure 7A). Nonetheless, there was an obvious variation during the non-growing season (Figure 7B)

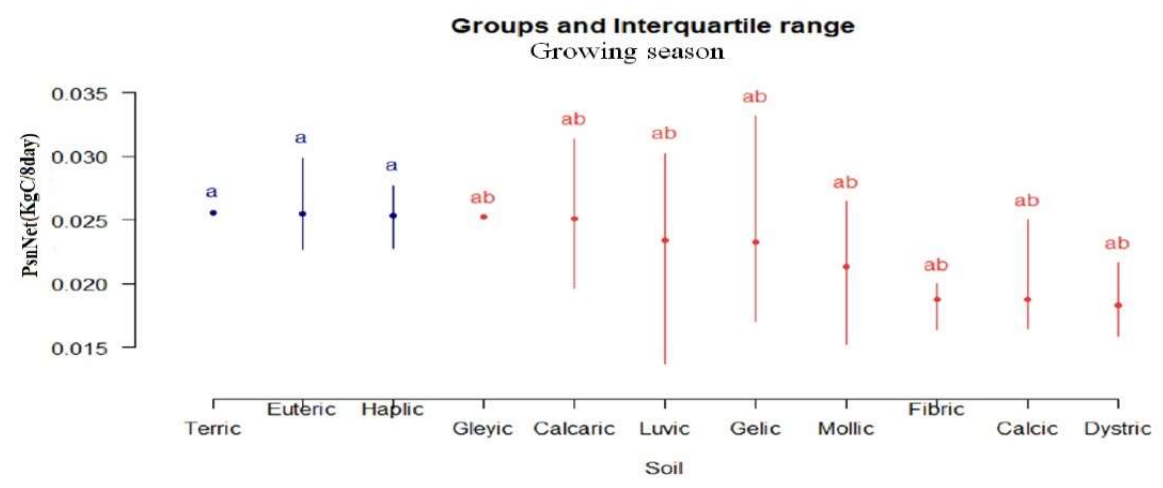

(a)

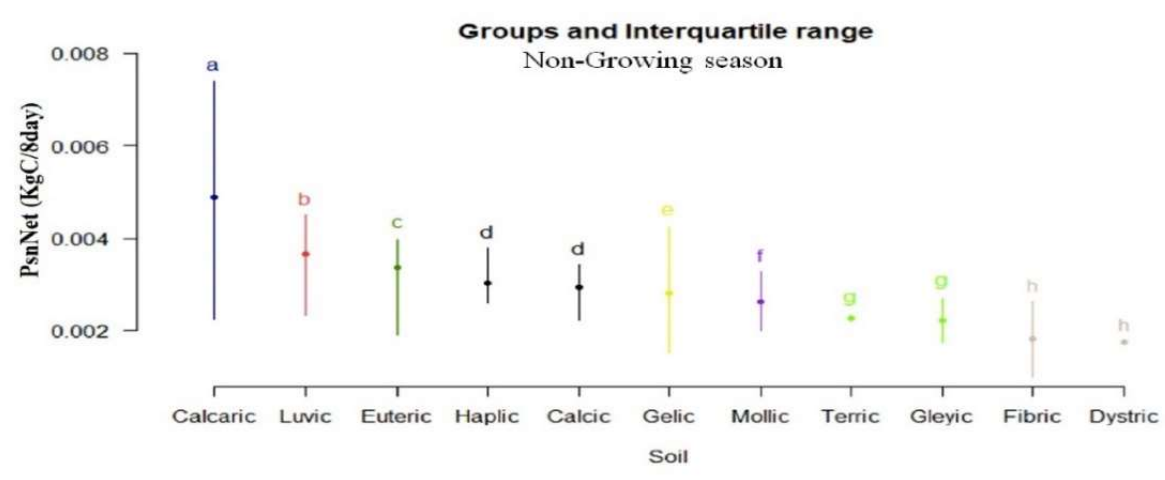

(b)

Figure 7. Groups and Interquartile Range (a) for Soil Type in the Growing Season (b) for Soil Type in the Non-Growing Season.

Treatments with the same letter are not significantly different.

In the growing season, Terric, Eutric, and Haplic form one group, thus they are not significantly different; they form one group. Also, Gleyic, Calcaric, Luvic, Gelic, Mollic, Fibric Calcic, and Dystric are not significantly different; they form another group (Figure 7A). This confirms that there was no significant variation among the soil types in the growing season. However, there was a large variation 
among the soil types in the non-growing season; 8 groups, as opposed to only two in the growing season, exist in the non-growing season (Figure $7 \mathrm{~B}$ ).

\subsection{Impact of Soil and Grassland Types Interaction on Net Photosynthesis}

The interaction between soil and grassland types was highly significant in both the growing and non-growing seasons (Tables $6 \mathrm{~A}$ and $\mathrm{B}$ ).

Table 6. ANOVA of Soil-Grass interaction effect on PsnNet (a) Growing Season (b) Non-growing Season.

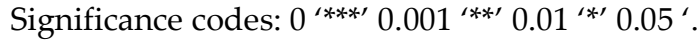

\begin{tabular}{cccccc}
\hline \multicolumn{6}{c}{ ANOVA (Growing season) } \\
\hline & Df & Sum Sq & Mean Sq & F-Value & $\operatorname{Pr}(>\mathrm{F})$ \\
\hline block & 3 & 0.00073 & $2.40 \mathrm{E}-04$ & 3.59 & $0.04645^{*}$ \\
\hline Sol: Grass & 41 & 0.0034 & $8.29 \mathrm{E}-05$ & 3.55 & $0.00000532^{* * *}$ \\
\hline
\end{tabular}

(a)

\begin{tabular}{cccccc}
\hline \multicolumn{6}{c}{ ANOVA (Non-Growing season) } \\
\hline & Df & Sum Sq & Mean Sq & F-Value & $\operatorname{Pr}(>\mathrm{F})$ \\
\hline block & 3 & $02.33 \mathrm{E}-05$ & $7.77 \mathrm{E}-06$ & 196.122 & $5.30 \mathrm{E}-15^{* * *}$ \\
\hline Sol: Grass & 41 & $2.96 \mathrm{E}-0.4$ & $7.32 \mathrm{E}-06$ & 16.122 & $2.20 \mathrm{E}-16^{* * *}$ \\
\hline
\end{tabular}

(b)

Furthermore, figure 8 shows the PsnNet of various grasses growing in particular soil types. For example, Marsh Meadows grow only in Mollic soils. Also, Halophytes grow in Eutric, Gelic, and Mollic soils. Alpine meadows and Subalpine deciduous broad-leaf shrubs grow in most soil types and are the most dominant grassland types.

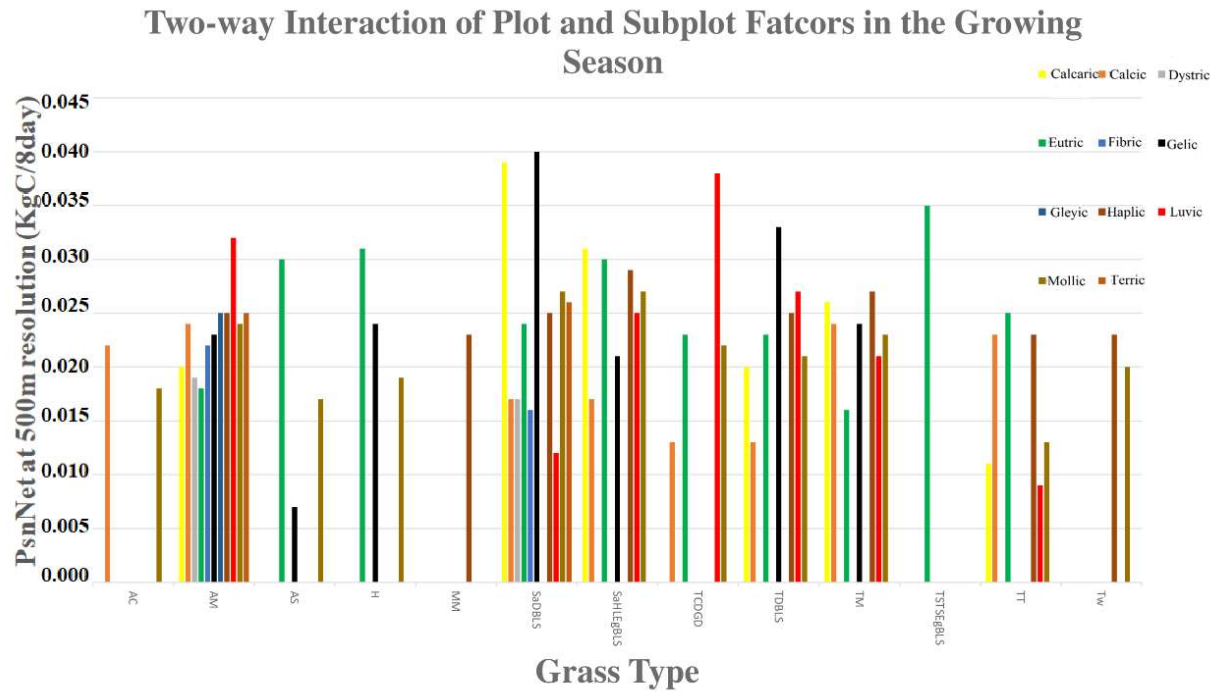

(a) 


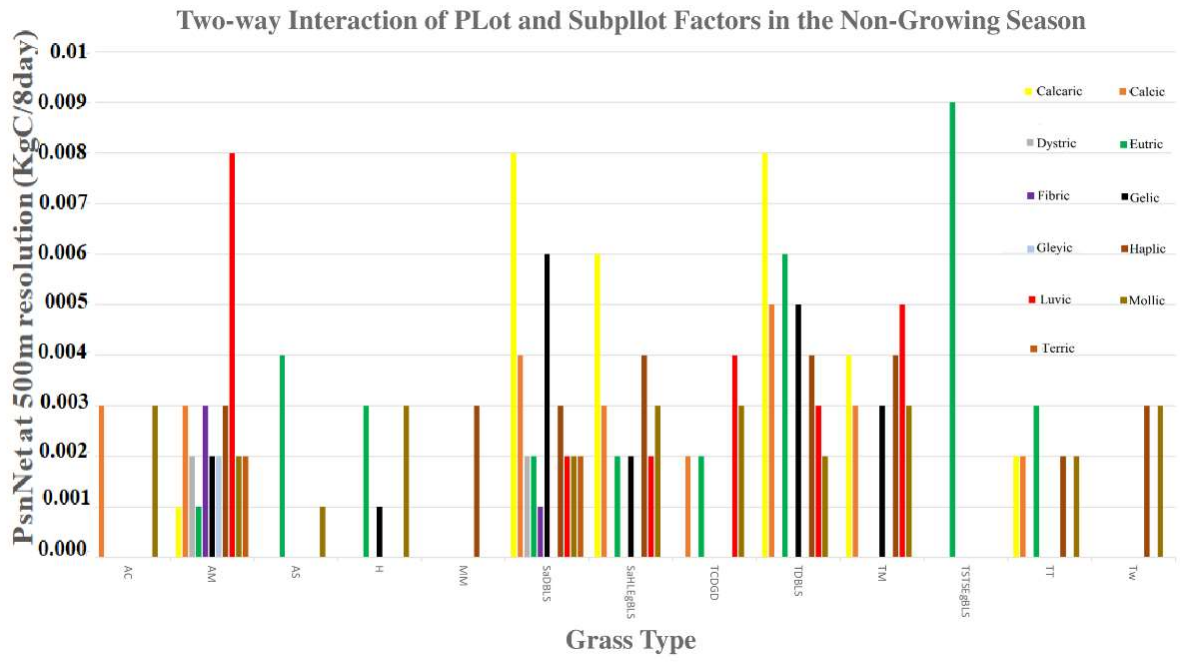

(b)

Figure 8. Two-way Interaction of Plot and Subplot Factors during the (a) growing season (b) non-growing season.

Key: AC-Alpine Cushion, AM-Alpine Meadows, AS-Alpine Sparse, H-Halophytes, MM-Marsh Meadows, SaDBLS - Sub-alpine Deciduous Broadleaf Shrubs, SaHLEBLS- Subalpine hard-leaf evergreen Broad-leaf Shrub, TCDGD- Tibetan Caragana \& Dwarf Grass Desert, TDBLS- Temperate deciduous broad-leaf Shrub, TM- Temperate Meadow, TSTSEgBLS - Trop. \& Subtropical. succulent evergreen broad-leaf Shrub, TT- Temperate Typical, Tw- Thorn weed

The values are the net photosynthesis at 500m resolution for each soil-grass interaction. Alpine meadows do best in Luvic soils but do poorly in Eutric soils in both the growing and non-growing seasons. Subalpine deciduous broad-leaf shrubs do the best in Calcaric and Gelic soils during the growing season. However, there is a stark difference between the performance in Calcaric and Gelic soils during the non-growing season. The photosynthesis of Subalpine Deciduous Broad-Leaf Shrubs in Mollic and Terric soils is far higher than that in Luvic soils during the growing season. However, all three were equal during the non-growing season. This signals a disproportional change in net photosynthesis between the two seasons. In general, the interaction effect between subalpine deciduous broad-leaf shrubs and Gelic soils triggers the highest photosynthesis during the growing season. Nonetheless, the interaction between Tropical and Subtropical Succulent Evergreen Broad-Leaf Shrubs and Eutric soils was the most productive in the non-growing season (Figure $8 B)$.

As mentioned above, we observed that the percentage changes in PsnNet for all soil-grass interactions between the two seasons were not proportional. As illustrated in Figure 9, about $40 \%$ of the photosynthetic activities of Temperate deciduous broad-leaf growing in Calcaric soils remain during the non-growing season. However, less than $10 \%$ remains in the Haplic soils. 


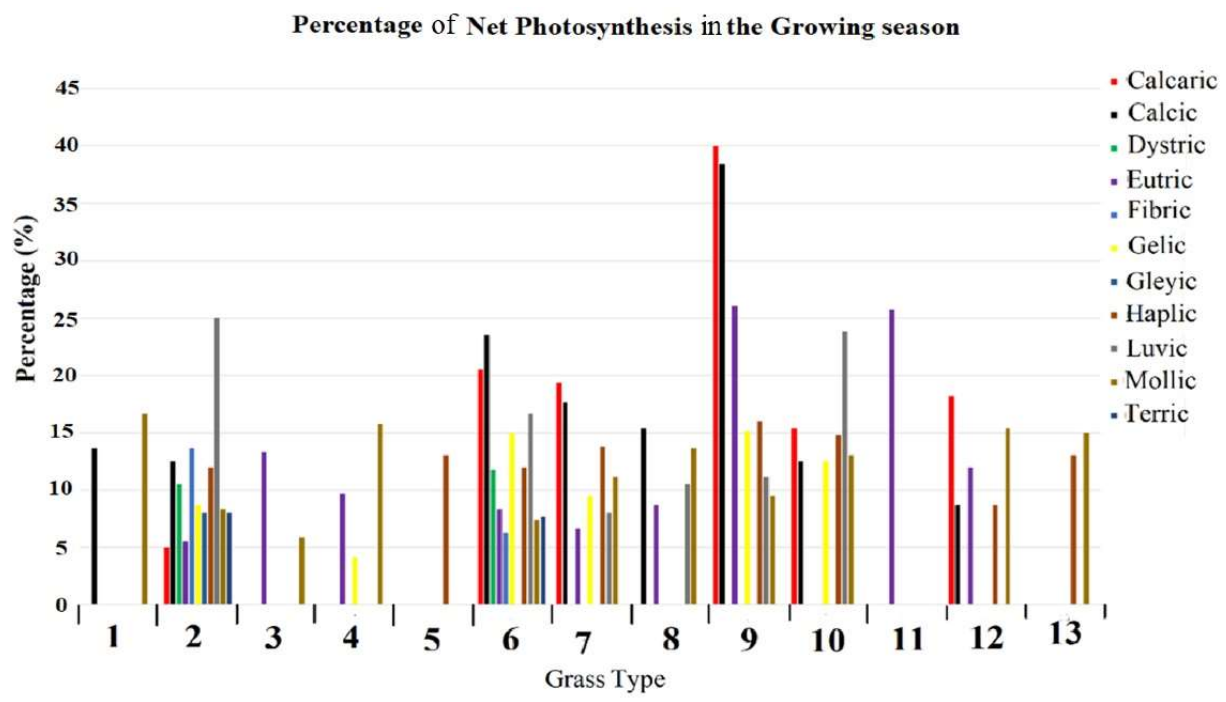

Figure 9. Percentage of PsnNet in the non-growing season.

Key: 1-Alpine Cushion, 2-Alpine Meadows, 3-Alpine Sparse, 4-Halophytes, 5-Marsh Meadows, 6- Sub-alpine Deciduous Broadleaf Shrubs, 7- Subalpine hard-leaf evergreen Broad-leaf Shrub, 8- Tibetan Caragana \& Dwarf Grass Desert, 9-Temperate deciduous broad-leaf Shrub, 10-Temperate Meadow, 11- Trop. \& Subtropical. succulent evergreen broad-leaf Shrub, 12- Temperate Typical, 13- Thorn weed

Again, $15 \%$ of the photosynthetic activities of Sub-alpine Deciduous Broadleaf Shrubs growing in Gelic soils remained during the non-growing season. However, approximately $24 \%$ of it remains in those growing in Calcic soils. The percentage change in the photosynthetic activities for the various soil-grass combinations is useful for determining which of them is most resilient and can withstand harsh weather conditions.

\section{Discussion}

The soils and grasslands of Gannan are not evenly distributed. For instance, Eutric and Calcic soils alone take up over $69 \%$ of the total land area (Table 1). Nonetheless, the other soil types support a good variety of grasses. For example, Gelic soils, which cover only $0.15 \%$ of the total area, support 6 different grassland types (Table 1, Fig. 8). In addition, Alpine meadows and Subalpine deciduous broad-leaf shrubs alone cover over $83 \%$ of the total land area (Table 2). However, at 500m resolution, they do not have the highest photosynthetic activities in Gannan. On the contrary, Tropical and subtropical succulent evergreen broad leaves and temperate meadows, which occupy only $0.081 \%$ of the total area, have the highest photosynthetic activities at a $500 \mathrm{~m}$ resolution, followed by Subalpine Deciduous Broad-Leaf Shrubs (Table 2, Figure 4). These are mainly located in the subalpine regions. Especially for Temperate Meadows and Tropical and Subtropical Deciduous Broad Leaf Shrubs, photosynthesis is year-round. This indicates that if these high productivity grasses had a larger coverage area, grassland productivity would increase enormously.

Notwithstanding, the grasslands of Gannan are showing improving vegetation health (Fig 2A ), thanks to Temperate meadows and Tropical and Subtropical succulent evergreen broad-leaf shrubs which show increasing trends for the study period (Fig. 4). This could be attributed to the various grassland reclamation projects by the Chinese gov- 
ernment over the years such as the "Retire Livestock and Restore Pastures" [25]. Generally, the Alpine regions have the lowest amount of photosynthesis as compared with the subalpine regions. This could be explained by the fact that there is occasional water runoff to the subalpine regions thereby keeping them wet at the expense of the alpine regions. Consequently, the subalpine regions have year-round soil water to support plant growth. Also, temperatures in the alpine regions are extremely low in the winters. As a result, soil water becomes frozen, thereby inhibiting plant growth [26-28]. This explains why location (block) has a significant effect in the non-growing season. (Table 5B). Additionally, some soil types have higher water retention capacities than others, and this may further contribute to disparities in photosynthesis.

We observe from the grouping analyses (Fig. 7) that a greater diversity exists among the soil types in the non-growing season than there is in the growing season. The soil effect on net photosynthesis in the growing season (Table 5A) is not significant. We conjecture that in the growing season, there are favorable weather and environmental conditions for all soil types to support plant life. There is sufficient rainfall for maximum production [29,30]. In this period, all soils exhibit their best and maximum agronomic properties [9]. However, soil effect on net photosynthesis is highly significant in the non-growing season (Table 5B). Again, this is because, in the non-growing season, harsh weather conditions may turn the odds against soil types that are highly sensitive to harsh weather conditions. In other words, different soils respond differently to different weather conditions, and hence their support for plant life may be affected differently [31,32]. It is important to note that Mollic, Gelic, and Haplic soils which interaction with grass triggers the highest photosynthetic activities only take up a little over $12 \%$ of the total area. Nevertheless, Eutric soils, which occupy over $40 \%$ of the total area are only fourth to the aforementioned soil types. (Fig 6B, Table 1). This is useful, as policymakers may have to pay special attention to these extremes.

Additionally, the variation of soil nutrients between seasons could also be a major factor. The role of soil nutrients in photosynthesis cannot be overestimated. For example, 3nutrient deficiency may lead to low production of chlorophyll [33]. Even though the annual and seasonal losses of the main nutrient elements are small according to Alías et al., [10] our findings show that soil effects on photosynthesis are different between the growing and non-growing seasons. If Alías et al. are right in their conclusion, we hypothesize that the small seasonal changes in the concentration of main nutrients are enough to make a difference. These variations are caused mainly by temperature and precipitation as observed by Patel, M.P.; Gami, B.; Patel B. [34]. In concordance with findings by other researchers, they concluded that with the change in precipitation and temperature regimes, physical properties and trace element concentration vary significantly [32, 34 and 35, 36]. Fatubarin and Olojugba also found that soil $\mathrm{pH}$ and available phosphorus were higher in the dry season than in the rainy season [29]. Additionally, Gentili et al observed that high $\mathrm{pH}$ values affect growth adversely [30], observing that plants grown at pH7 were shorter and developed leaves at a slower rate than those grown at pH5 and pH6. At the same time, soil organic matter and total nitrogen (essential for plant growth) were low, but nitrogen content increased at the peak of the rainy season due to nitrogen fixation [31]. Other researchers also confirm soil properties vary with seasons [37, 38]. In a nutshell, the amount of soil nutrients changes with seasons.

Directly linked to the seasonal variation of soil nutrients is the activities of soil microbes as observed by. Xue et al. They showed that soil microbial communities directly affect soil functionality by cycling soil nutrients and carbon storage [39]. They concluded that microbial communities vary in space and time, between soil types and under different land management. These variations, they claimed are governed by soil properties. As has been shown, soil properties vary with season. This implies that different soils support microbial growth to different degrees in different seasons, which may alter the main soil nutrients from season to season. This seasonal variation of nutrients and environmental factors could cause seasonal variation in photosynthesis. For example, the net photosynthesis of Alpine Cushion in Calcic and Mollic soils are equal in the non-growing season. 
However, it increased more in Calcic soils than it did in Mollic soils in the growing season (Figure 8). Furthermore, the net photosynthesis of Subalpine Deciduous Broad-Leaf Shrubs in Luvic, Molllic, and Terric soils are equal in the non-growing season. Nonetheless, photosynthesis in Luvic soils lags those in Mollic and Terric soils in the growing season (Fig 8). A similar phenomenon could be observed across the various soil-grass types interactions.

Another important reason is the variations in phonological response to seasonal changes among the various grass types. Chang et al [40] confirm this in their research on European grasslands. They established that there is a significant phenology shift, particularly in an earlier winter-spring onset of grass growth over Europe. This phenology shift differs among grasses, thereby affecting their productivity curves. Also Digrado et al.[32] confirm that plants respond differently under stressed conditions observing that decreased photosynthetic performance was associated with high respiration flux. Their study revealed that variation in the photosynthetic performance of a grassland ecosystem responded to environmental constraints. This can be confirmed by the fact that there is an unequal percentage change in productivity from the growing season to the non-growing season among the various soil-grass combinations (Fig 9). This is illustrated by [18] showing that the Leaf Area Index (LAI) exhibited large seasonal change. It is therefore clear that soil and grassland types all contribute to the seasonal variation of photosynthesis in Gannan. Consequently, the interaction effect between soil and grassland types is highly significant in both seasons.

\section{Conclusions}

In this study, we have established that the effect of soil on grassland photosynthesis varies between seasons (growing and non-growing seasons). It is highly significant in the non-growing season but not significant in the growing season. However, the effects of grassland type on grassland photosynthesis are highly significant in both seasons. In addition, the interaction of the soil-grass type has a highly significant effect on net photosynthesis. Grassland health in Gannan is gradually trending up but only prominent in areas dominated by Temperate Meadows and Subalpine Deciduous Broad-leaf Shrubs. We hope that our findings would be informative to policymakers in selecting not only which grassland type to focus on, but also which soil type to improve.

We recommend that Temperate Meadows be given special attention since their production is high, second only to Tropical and Subtropical Succulent Evergreen Broad-leaf Shrubs. In addition, areas occupied by Eutric soils in Gannan should be given special management care. In future grassland restoration projects, areas occupied by Mollic, Gelic, and Haplic soils should be a priority as their interaction with grasses triggers the highest photosynthetic activities. This would in turn accelerate the absorption of atmospheric carbon, thereby mitigating global warming.

Supplementary Materials: The following are available online at www.mdpi.com/xxx/s1, Figure S1: title, Table S1: title, Video S1: title.

Author Contributions: “Conceptualization, Z.M. and N.S.; methodology, N.S.; software, N.S.; validation, Z.M., N.S., and N.T.; formal analysis, N.S.; investigation, N.S.; resources, W.X.; data curation, H.S.; writing-original draft preparation, N.S.; writing-review and editing, Z.M.; visualization, N.T.; supervision, Z.M.; project administration, Z.M.; funding acquisition, Z.M. All authors have read and agreed to the published version of the manuscript."

Funding: This research was funded by the Young Tutor Support Fund Project of the Gansu Agriculture University, No. GAU-QDFC-2019-03; the Research Fund of Higher Education of Gansu, China, No. 2019A-051; the Natural Science Foundation of Gansu Province, China, No. 1606RJZA077 and 1308RJZA262.

Data Availability Statement: In this section, please provide details regarding where data supporting reported results can be found, including links to publicly archived datasets analyzed or gener- 
ated during the study. Please refer to suggested Data Availability Statements in section “MDPI Research Data Policies" at https://www.mdpi.com/ethics. You might choose to exclude this statement if the study did not report any data.

Conflicts of Interest: The authors declare no conflict of interest. The funders had no role in the design of the study; in the collection, analyses, or interpretation of data; in the writing of the manuscript, or in the decision to publish the results.

\section{References}

1. Wohlfahrt, G.; Gu L. Plant Cell Environ. 2015 Dec; 38(12): 2500-2507. Published online 2015 Jun 25. doi: 10.1111/pce.12569

2. Yang, Y.; Tilman, D.; Furey, G.; Lehman, C. Soil carbon sequestration accelerated by restoration of grassland biodiversity. Nature Communications 2019, 10(1). doi:10.1038/s41467-019-08636-w

3. Lal, R. Soil carbon sequestration to mitigate climate change. Geoderma 2004, 123, 1-22.

4. Silver, W. L.; Ostertag, R.; Lugo, A. E. The potential for carbon sequestration through reforestation of abandoned tropical agricultural and pasture lands. Restor. Ecol. 2000 8, 394-407.

5. Novara, A. et al. Agricultural land abandonment in Mediterranean environment provides ecosystem services via soil carbon sequestration. Sci. Total Environ 2017 576, 420-429.

6. Dass, P.; Houlton B.Z.; Yingping Wang, Y.; Warlind, D. Published 10 July $2018 \bullet$ @ 2018 The Author(s). Published by IOP Publishing Ltd Environmental Research Letters, Volume 13, Number 7Citation Pawlok Dass et al 2018 Environ. Res. Lett. 13074027

7. Li, Y.; Li, J.; Are, K. S.; Huang, Z.; Yu, H.; Zhang, Q. Livestock grazing significantly accelerates soil erosion more than climate change in Qinghai-Tibet Plateau: Evidenced from 137Cs and 210Pbex measurements. Ecosystems \& Environment 2019, 285; 106643. doi:10.1016/j.agee.2019.106643

8. Chen; L.; Wei; W.; Fu; B.; \& Lü; Y. Soil and water conservation on the Loess Plateau in China: review and perspective. PPG 2007, 31(4); 389-403. doi:10.1177/0309133307081290

9. Stuart Chapin III, F.; McFarland, J.; David McGuire, A.; Euskirchen, E. S.; Ruess, R. W.; Kielland, K. The changing global carbon cycle: linking plant-soil carbon dynamics to global consequences. JE 2009, 97(5); 840-850. doi:10.1111/j.13652745.2009.01529.x

10. Alías, L. J.; López-Bermúdez, F.; Marín-Sanleandro, P.; Romero-Díaz, M. A.; Martínez, J. Clay minerals and soil fertility loss on Petric Calcisol under a semiarid Mediterranean environment. ST 1997, 10(1); 9-19. doi:10.1016/0933-3630(95)00044-5

11. Loera-Sánchez, M.; Studer, B.;Kölliker, R. DNA-Based Assessment of Genetic Diversity in Grassland Plant Species: Challenges, Approaches, and Applications , Agronomy 2019, 9, 881; doi:10.3390/agronomy9120881

12. Epstein, H.E.; Lauenroth, W.K.; Burke, I.C.; Coffin, D.P. Regional productivities of plant species in the Great Plains of the United States. PE 1998,134: 173-195.

13. Fay, P.A.; Jin, V.L.; Way, D.A.; Potter, K.N.; Gill, R.A.; Jackson, R.B.; Polley, H.W. Soil-mediated effects of subambient to increased carbon dioxide on grassland productivity. NCC 2012, 2: 742-746.

14. Garcia-Palacios, P.; Maestre, F.T.; Bardgett, R.D.; de Kroon, H. Plant responses to soil heterogeneity and global environmental change. JE 2012, 100: 1303-1314

15. Misra, M. K.; Misra, B. N. Seasonal Changes in Leaf Area Index and Chlorophyll in an Indian Grassland. TJE 1981, 69(3); 797. doi:10.2307/2259637

16. Wu, D.; Zou, C.; Cao, W.; Xiao, T.; Gong, G. Ecosystem services changes between 2000 and 2015 in the Loess Plateau; China: A response to ecological restoration. PLOS ONE 2019, 14(1); e0209483. doi:10.1371/journal.pone.0209483

17. Chen; J.; Hou; F.; Chen; X.; Wan; X.; \& Millner; J. Stocking Rate and Grazing Season Modify Soil Respiration on the Loess Plateau; China. REM 2015, 68(1); 48-53. doi:10.1016/j.rama.2014.12.002

18. Maguigan, M.; Rodgers, J.; Dash, P.; Meng, Q.M. Assessing Net Primary Production in Montane Wetlands from Proximal; Airborne; and Satellite Remote Sensing. ARS 2016, 5; 118-130.

19. Yang, P.; Feng, Q.; Hong, G.; Kattawar, G.W.; Wiscombe, W.J.; Mishchenko, M.I.; Dubovik, O.; Laszlo, I.; Sokolik, I.N. Modeling of the scattering and radiative properties of nonspherical dust-like aerosols. J. Aerosol Sci. 2007, 38; 995-1014; doi:10.1016/j.jaerosci.2007.07.001.

20. http://www.ecosystem.csdb.cn/. Available online: (accessed on 22nd October 2020)

21. Soil Maps and Databases. Available online: http://www.fao.org/soils-portal/data-hub/soil-maps-and-databases/harmonizedworld-soil-database-v12/en/. Available online: (accessed on 20th October 2020)

22. Shi, X.Z.; Yu, D.S.; Warner, E.D.; Pan, X.Z.; Petersen, G.W.; Gong, Z.G.; Weindorf, D.C. Soil Database of 1:1;000;000 DSSR 2004

23. LP DAAC. Available online: https://lpdaac.usgs.gov. Available online: (accessed on 30th October 2020)

24. Steven, W.; Zhao, R.M. User's Guide Daily GPP and Annual NPP (MOD17A2H/A3H) and Year-end GapFilled (MOD17A2HGF/A3HGF) Products NASA Earth Observing System MODIS Land Algorithm (For Collection 6), Version 4.2 June 10th, 2019

25. Wang, Y.; Sun, Y.; Wang, Z.; Chang, S.; Hou, F. Grazing management options for restoration of alpine grasslands on the Qinghai-Tibet Plateau. ECOSPHERE, 2018, Vol.9, Issue11 https://doi.org/10.1002/ecs2.2515 
26. ÖQUIST, G. Effects of low temperature on photosynthesis. PCEE 1983, Volume6, Issue4, https://doi.org/10.1111/13653040.ep11612087

27. Hurry, V.; Druart, N.; Cavaco, A.; Gardeström, P.; Strand, Å. (2002) Photosynthesis at Low Temperatures. In: Li P.H., Palva E.T. (eds) Plant Cold Hardiness. Springer, Boston, MA. https://doi.org/10.1007/978-1-4615-0711-6_12

28. Fatubarin, A.; Olojugba, M. R. Effect of rainfall season on the chemical properties of the soil of a Southern Guinea Savanna ecosystem in Nigeria. JENE 2014, Vol. 6(4), pp. 182-189, DOI: 10.5897/JENE2013.0433

29. Gentili, R.; Ambrosini, R.; Montagnani, C.; Caronni, S.; Citterio, S. (2018) Effect of Soil pH on the Growth, Reproductive Investment and Pollen Allergenicity of Ambrosia artemisiifolia L. Front. Plant Sci. 2018 9:1335. doi: 10.3389/fpls.2018.01335

30. What Is the Nitrogen Cycle and Why Is It Key to Life? Available online https://kids.frontiersin.org/ (accesses on $15^{\text {th }}$ February, 2021)

31. Digrado, A.; Louis, G. de la Motte, Bachy, A.; Mozaffar, A.; Schoon, N.; Bussotti, F.; Amelynck, C.; Dalcq, A.C.; Fauconnier, M.L.; Aubinet, M.; Heinesch, B.; du Jardin, P. Delaplace, P. Decrease in the Photosynthetic Performance of Temperate Grassland Species Does Not Lead to a Decline in the Gross Primary Production of the Ecosystem. Front. Plant Sci. 201805 | https://doi.org/10.3389/fpls.2018.00067

32. How Cold Weather Affects Plants. Available online: https://www.envii.co.uk/garden-blog-post/cold-weather-affects-plants (accessed on 20th February, 2021)

33. Morgan, J. B.; Connolly, E. L. (2013) Plant-Soil Interactions: Nutrient Uptake. Nature Education Knowledge 4(8):2

34. Patel, M.P.; Gami, B.; Patel B. Seasonal Impact on Physical-Chemical Properties of Soil in North and South Gujarat. IOSRJAVS 2015, Volume 8, Issue 6 Ver. II (Jun. 2015), PP. 26-36

35. The Function Of Phosphorus In Plants And The Garden. Available online: gardeningknowhow.com (accessed on $20^{\text {th }}$ February, 2021)

36. Cations and Cation Exchange Capacity - Fact Sheets . Available online: soilquality.org.au (accessed on 25 $5^{\text {th }}$ February, 2021)

37. Omer, M.; Idowu, O. J.; Ulery, A. L.; VanLeeuwen, D.; Guldan S. J. Seasonal Changes of Soil Quality Indicators in Selected Arid Cropping Systems. Agriculture 2018, 8, 124; doi:10.3390/agriculture8080124

38. Jirků, V.A.; Kodešová, R.A.; Mühlhanselová, M.A.; Žigová, A.B. Seasonal variability of soil structure and soil hydraulic properties. WCSSSSCW 2010

39. Xue, P.P.; Carrillo, Y.; Pino, V. et al. Soil Properties Drive Microbial Community Structure in a Large Scale Transect in South Eastern Australia. Sci 2018, Rep 8; 11725 (2018). https://doi.org/10.1038/s41598-018-30005-8

40. Chang; J.; Ciais; P.; Viovy; N. et al. Future productivity and phenology changes in European grasslands for different warming levels: implications for grassland management and carbon balance. CBM 2017, 12; 11 (2017). https://doi.org/10.1186/s13021017-0079-8 